\title{
Impact of Cluster Front Line Demonstrations on Productivity and Economics of Lentil (Lens culinaris L.), Chickpea (Cicer aeritinum L.) and Field Pea (Pisum sativum L.) in Old Alluvial Zone of Malda, West Bengal, India
}

Paramita Bhowmik, Paramita Biswas ${ }^{1}$, Suddhasuchi Das

10.18805/LR-4705

\begin{abstract}
Background: There are significant gaps in yields of pulses among potential, demonstration and farmers' plots in West Bengal. This is mostly due to adoption of traditional local varieties and poor cultivation practices.

Methods: The yield, technology and extension gaps were studied on improved varieties of lentil, chickpea and field pea during rabi seasons of 2017/18-2020/21 in 80 hectare area of Malda, West Bengal with 205 farmers.

Result: The highest and lowest magnitude of technology index (TI) was observed in field pea var. IPFD-10-12 (44.5\%) during 2018/ 19 and in lentil var. KL-320 (30.1\%) during 2020/21. Among lentil varieties, the highest benefit cost ratio was obtained from KL-320 (2.87) whereas in case of chickpea, it was obtained from NBEG-49 (2.90). For field pea var. IPFD-10-12 the benefit cost ratio was 2.70. Maximum and minimum extension yield gaps were observed in field pea var. IPFD-10-12 (451 kg ha $\left.{ }^{-1}\right)$ during $2018 / 19$ and in lentil var. IPL-406 (145 $\left.\mathrm{kg} \mathrm{ha}^{-1}\right)$ during 2018/19. Overall assessment reflects lentil var. KL-320, chickpea variety NBEG-49 and field pea variety IPFD-10-12 have good potentiality and most suitable for this region. So, it is hypothesized that improved farm technology has enormous potential to scale up pulse productivity through cluster front line demonstration (CFLD).

Key words: CFLD, Chickpea, Extension gap, Field pea, Lentil, Productivity, Technology gap, Technology index.
\end{abstract}

\section{INRODUCTION}

Pulses on account of their vital role in nutritional security and soil ameliorative properties have been integral part of sustainable agriculture over millennia. It is a rich source of protein and essential amino acids such as lysine complementing cereal proteins for most of the vegetarian population of the country. India is the largest producer $(25 \%)$, consumer $(27 \%)$ as well as importer $(14 \%)$ of pulses in the world (FAO, 2018). In 2018/19, total production, area of cultivation and yield of pulses in India were 23.40 million tonnes, 29.03 million hectares and $806 \mathrm{~kg} \mathrm{ha}^{-1}$, respectively, whereas in West Bengal those were 0.48 million tonnes, 0.51 million hectares and $944 \mathrm{~kg} \mathrm{ha}^{-1}$, respectively (Anonymous, 2019).

Lentil, chickpea and field pea are important (rabi) pulse crop and they occupy a major position among pulses in West Bengal. Lentil is the most predominant pulse crop in West Bengal followed by maskalai, khesari and chickpea (Anonymous, 2016). Lentil and chickpea productions in India during 2018/19 were 1.56 million tonnes and 10.13 million tones, respectively from the area of 1.51 million hectares and 9.44 million hectares, respectively (Anonymous, 2019). In West Bengal, area of production and productivity of lentil in $2018 / 19$ were 0.19 million hectares and 0.17 million tonnes, respectively (Anonymous, 2019). Leading pulse producing districts of West Bengal are Nadia, Murshidabad, North 24 Parganas and Birbhum; whereas, the overall scenario of pulse production in Malda district is not up to the mark.
Malda Krishi Vigyan Kendra, Block Seed Farm, Uttar Banga Krishi Viswavidyalaya, Ratua-732 205, Malda, West Bengal, India. ${ }^{1}$ Regional Research Sub Station (OAZ), Uttar Banga Krishi Viswavidyalaya, Mathurapur-732 202, Malda, West Bengal, India.

Corresponding Author: Paramita Bhowmik, Malda Krishi Vigyan Kendra, Block Seed Farm, Uttar Banga Krishi Viswavidyalaya, Ratua-732 205, Malda, West Bengal, India.

Email: paramita.bhowmik2@gmail.com

How to cite this article: Bhowmik, P., Krishi, M., Kendra, V. (2021). Impact of Cluster Front Line Demonstrations on Productivity and Economics of Lentil (Lens culinaris L.), Chickpea (Cicer aeritinum L.) and Field Pea (Pisum sativum L.) in Old Alluvial Zone of Malda, West Bengal, India. Legume Research. DOI: 10.18805/ LR-4705.

Submitted: 22-06-2021 Accepted: 08-11-2021 Online: 01-01-2021

The demand for pulses steadily increased due to increased population but production is more or less stagnant mostly due to several agro ecological, biological, socioeconomic and technical constraints. As a result there is widening of gap between supply and demand which led to increase in prices thereby it became out of reach to most of the common people. In last six decades, pulse production growth is only $32 \%$ which is far behind as compared to cereals which account $280 \%$ growth (Vilas et al. 2018). Most of the farmers in India are small and marginal. Due to the lack of financial support, low level of education and 
Impact of Cluster Front Line Demonstrations on Productivity and Economics of Lentil (Lens culinaris L.), Chickpea....

communication gap with research organizations, they are not familiar enough with the modern research and inventions on agriculture till date. So, most of the farmers are still using traditional or local knowledge for farming which leads to poor productivity and profitability and is a threat for future agriculture and livelihood security. Due to the stagnation and increased population, there is a sharp decline in per capita availability of pulses in India from $69 \mathrm{~g}^{\text {day }}{ }^{1}$ in 1961 to $33 \mathrm{~g}$ day $^{1}$ in 2009/10 (ICMR recommends $65 \mathrm{~g} \mathrm{day}^{1}$ capita $^{-1}$ ) (Ali and Gupta, 2012). In 2050, pulse production will have to grow at an annual rate of around $2.2 \%$ to meet projected demand of 39 million tonnes (Indian Institute of Pulse Research, 2015). Thus, to meet national and local pulse requirement, it is an utmost challenge for policy makers, farm scientists and extension functionaries as well as farming communities to enhance average pulse productivity up to $1200 \mathrm{~kg} \mathrm{ha}^{-1}$ by 2020 (The Hindu, 2005) by diversifying their cropping systems. Since 2010/11, ICAR had initiated well designed programme of technology demonstration for harnessing pulses productivity in 11 states through KVKs by involved in planning, execution and monitoring of the demonstrations for the technologies developed by them and farmers provide direct feedback from the farmers' fields about production. The main objective of CFLD is to disseminate and popularize proven improved production farm technologies to farmers to fill the gap between improved technology adopted and indigenous technology to ensure enhanced productivity and profitability in a sustainable manner for their livelihood security.

The present comprehensive study was undertaken to analyze the impact of proven improved technology transfer through CFLDs in pulses during 2017/18-2020/21 to target farmers in Malda district of West Bengal.

\section{MATERIALS AND METHODS}

Cluster Frontline Demonstrations (CFLDs) on improved technology (Table 1, 2 and 3) were conducted by Malda Krishi Vigyan Kendra of West Bengal in rabi pulse crops viz. lentil, chickpea and field pea during 2017/18-2020/21 under irrigated conditions on 80 hectare area covering 205 farmers. The study area is located in Old Alluvial Zone of Malda, West Bengal with tropical to sub-tropical climate. Location and soil properties of the experimental fields are reflected in Table 4. Soil testing $(\mathrm{pH}$, organic carbon, available $\mathrm{N}, \mathrm{P}, \mathrm{K}, \mathrm{B}, \mathrm{Zn}$ ) was done by the instrument MRIDAPARIKSHAK (MINILAB, Developed by ICAR, Indian Institute of Soil Science, Bhopal). In CFLDs' plots, full package of recommended practices were adopted whereas, in the adjoining farmers' fields, crops were grown as per farmers' practices which served as control/local check.

\section{Collection of data}

The data of grain yield in demonstrations' and farmers' practices were collected from the beneficiary farmers through personal interviews followed by tabulation and analysis to reach the conclusion. The increased yield in demonstrations over farmers' practice was calculated by using the following formula:

$\%$ Yield increase over farmers' practice (\%YIOFP) $=$

Average plot yield of demonstration-

Average plot yield of farmers

Average plot yield of farmers

Technology gap, extension gap and technology index were calculated by using the formulae stated below: (Kadian et al. 1997):

$$
\text { Technology index }(\%)=\frac{\text { Technology gap }}{\text { Protential yield }} \times 100
$$

Extension gap = Demonstration yield- Farmers' yield (control). Technology gap = Potential yield- Demonstration yield .

\section{Economic analysis}

Economics were computed based on current market prices for input and outputs.

\section{RESULTS AND DISCUSSION} Yield performance

\section{Lentil}

The average yield and percent yield increase over control with IPL-406 variety was recorded $843 \mathrm{~kg} \mathrm{ha}^{-1}$ and $23.8 \%$ during 2017/18 and $897 \mathrm{~kg} \mathrm{ha}^{-1}$ and $19.3 \%$ during 2018/19, respectively. The variety KL-320 showed $1119 \mathrm{~kg} \mathrm{ha}^{-1}$ yield and $40.2 \%$ yield increase over farmer's plot during 2020/21.

\section{Chickpea}

The average productivity of JAKI-9218 variety varied from $1155 \mathrm{~kg} \mathrm{ha}^{-1}(2017 / 18)$ to $1234 \mathrm{~kg} \mathrm{ha}^{-1}(2018 / 19)$ with $54.4 \%$ (2017/18) and 52\% (2018/19) yield increase over farmers' plot. The variety NBEG-49 showed $1298 \mathrm{~kg} \mathrm{ha}^{-1}$ yield and $51.8 \%$ yield increase over farmers' plot during 2020/21.

\section{Field pea}

Demonstration plots with field pea variety IPFD-10-12 showed $1387 \mathrm{~kg} \mathrm{ha}^{-1}$ yield and $48.2 \%$ yield increase over control during 2018/19.

Seed treatments with rhizobium culture improve nodulation and better fixation of nitrogen in legumes which improve yield (Laguerre et al. 2007). So, in demonstration plots seed treatments were done with rhizobium to enhance productivity. The yield potentiality of local variety is quite low because the varieties are old and more prone to disease and pest. The variety in demonstration like chickpea var. JAKI-9218 is resistant to fusarium wilt, root rot and collar rot and NBEG-49 is tolerant to wilt. Lentil var. IPL-406 is resistant to rust and KL-320 is moderately resistant to wilt and rust. Field pea var. IPFD-10-12 is a resistant to powdery mildew and tolerant to rust. These special characters of these varieties minimized the cost of cultivation of the pulse crops by reducing the injudicious application of pesticides against these diseases which ultimately increased the yield in demonstration. 
Impact of Cluster Front Line Demonstrations on Productivity and Economics of Lentil (Lens culinaris L.), Chickpea....

\section{Extension yield gap}

Successful research planning and suitable methodologies are important for development and implementation of recent advanced technologies. Extension gap can be minimized by bringing awareness and motivation among the farmers for acceptance and adoption of improved technologies in place of their traditional practices (Cramb, 2003).

Table 1: Cluster frontline demonstrations on improved technology of lentil.

\begin{tabular}{|c|c|c|c|}
\hline $\begin{array}{l}\text { Technology } \\
\text { component }\end{array}$ & Demonstration package & Farmers' practices & GAP \\
\hline Variety & IPL-406, KL-320 & WBL-58 & Full gap \\
\hline Seed rate & $50 \mathrm{~kg} \mathrm{ha}^{-1}$ & $60 \mathrm{~kg} \mathrm{ha}^{-1}$ & Higher seed rate \\
\hline Spacing & $25 \mathrm{~cm} \times 10 \mathrm{~cm}$ & Broadcasting & Full gap \\
\hline Sowing time & $1^{\text {st }}$ week of November & $1^{\text {st }}$ week of December & Late sowing \\
\hline Seed treatment & $\begin{array}{l}\text { Rhizobium culture and PSB } 1 \times 10^{7} \mathrm{CFU} \mathrm{g} \mathrm{g}^{-1} @ 10 \mathrm{gm} \mathrm{kg}^{-1} \\
\text { of seed one day before sowing of seeds }\end{array}$ & No seed treatment & Full gap \\
\hline Fertilizer (NPK as basal) & $\mathrm{N}: \mathrm{P}_{2} \mathrm{O}_{5}: \mathrm{K}_{2} \mathrm{O}\left(20: 40: 40 \mathrm{~kg} \mathrm{ha}^{-1}\right), \mathrm{ZnSO}_{4} @ 20 \mathrm{~kg} \mathrm{ha}^{-1}$ & $10: 10: 10$ & Lower doses \\
\hline D.A.P. & $2 \%$ D.A.P. @ $9 \mathrm{~kg} \mathrm{ha}^{-1}$ at 30 DAS as foliar spray & No such treatment & Full gap \\
\hline Micronutrients & $\begin{array}{l}\text { Micronutrient grade } \mathrm{V} @ 900 \mathrm{ml} \mathrm{ha}^{-1} \text { at } 35 \text { DAS during } \\
\text { vegetative stage and at } 60 \text { DAS during pre-flowering } \\
\text { stage with sticker @ } 225 \mathrm{ml} \mathrm{ha}^{-1}\end{array}$ & No such treatment & Full gap \\
\hline Irrigation & Pre flowering and pod initiation stage & One at 30 DAS & Partial gap \\
\hline Soil Treatment & 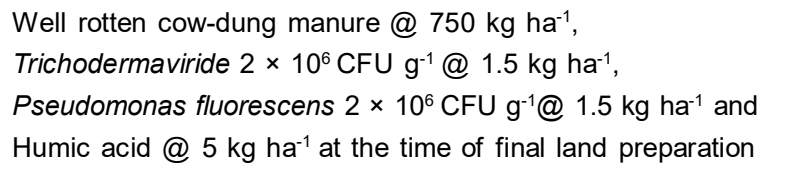 & No such treatment & Full gap \\
\hline Weed management & $\begin{array}{l}\text { Pendimethalin } 30 \% \text { as PE @ } 0.75 \mathrm{~kg} \text { a.i. ha }{ }^{-1}+\text { Imazethapyr } \\
\text { @ } 25 \mathrm{~g} \text { a.i. ha-1 as POE }\end{array}$ & One hand weeding & Uneconomical \\
\hline Plant protection & Azoxystrobin $11 \%+$ Mancozeb $18.3 \% @ 2 \mathrm{ml} \mathrm{l}^{-1}$ at 50 DAS & No such practice & Full gap \\
\hline
\end{tabular}

Table 2: Cluster frontline demonstrations on improved technology of chickpea.

\begin{tabular}{|c|c|c|c|}
\hline $\begin{array}{l}\text { Technology } \\
\text { component }\end{array}$ & Demonstration package & Farmers' practices & GAP \\
\hline Variety & Jaki-9218/NBEG-49 & B-108 & Full gap \\
\hline Seed rate & $60 \mathrm{~kg} \mathrm{ha}^{-1}$ & $70 \mathrm{~kg} \mathrm{ha}^{-1}$ & Higher seed rate \\
\hline Spacing & $30 \mathrm{~cm} \times 10 \mathrm{~cm}$ & Broadcasting & Full gap \\
\hline Sowing time & $2^{\text {nd }}$ week of November & $4^{\text {th }}$ week of November & Late sowing \\
\hline Seed treatment & $\begin{array}{l}\text { Rhizobium culture and PSB } 1 \times 10^{7} \mathrm{CFU} \mathrm{g} \mathrm{g}^{-1} @ \\
10 \mathrm{gm} \mathrm{kg}^{-1} \text { of seed one day before sowing of } \\
\text { seeds }\end{array}$ & No seed treatment & Full gap \\
\hline $\begin{array}{l}\text { Fertilizer } \\
\text { (NPK as basal) }\end{array}$ & $\begin{array}{l}\mathrm{N}: \mathrm{P}_{2} \mathrm{O}_{5}: \mathrm{K}_{2} \mathrm{O}\left(20: 40: 40 \mathrm{~kg} \mathrm{ha}^{-1}\right), \mathrm{ZnSO}_{4} @ \\
20 \mathrm{~kg} \mathrm{ha}^{-1}\end{array}$ & 10:10:10 & Lower doses \\
\hline D.A.P. & $2 \%$ D.A.P. @ $9 \mathrm{~kg} \mathrm{ha}^{-1}$ at 30 DAS as foliar spray & No such treatment & Full gap \\
\hline Micronutrients & $\begin{array}{l}\text { Micronutrient grade } \mathrm{V} @ 900 \mathrm{ml} \mathrm{ha}^{-1} \text { at } 35 \text { DAS } \\
\text { vegetative stage and at } 60 \text { DAS during pre- } \\
\text { flowering stage with sticker @ } 225 \mathrm{ml} \mathrm{ha}^{-1}\end{array}$ & No such treatment & Full gap \\
\hline Irrigation & Pre flowering and pod initiation stage & One at 35 DAS & Partial gap \\
\hline Soil treatment & $\begin{array}{l}\text { Well rotten cow-dung manure @ } 750 \mathrm{~kg} \mathrm{ha}^{-1} \text { and } \\
\text { Trichodermaviride } 2 \times 10^{6} \mathrm{CFU} \mathrm{g} \mathrm{g}^{-1} @ 1.5 \mathrm{~kg} \mathrm{ha}^{-1} \\
\text { and Pseudomonas fluorescens } 2 \times 10^{6} \mathrm{CFU} \mathrm{g}{ }^{-1} @ \\
1.5 \mathrm{~kg} \mathrm{ha}^{-1} \text { and Humic acid } @ 5 \mathrm{~kg} \mathrm{ha}^{-1} \text { at the } \\
\text { time of final land preparation }\end{array}$ & No such treatment & Full gap \\
\hline Weed management & Pendimethalin 30\% as PE @ 0.75 kg a.i ha ${ }^{-1}$ & One hand weeding & Uneconomical \\
\hline Plant protection & $\begin{array}{l}\text { Novaluron } 5.25 \%+\text { Emamectin benzoate } 0.9 \% \\
\text { SC @ } 2 \mathrm{ml} \mathrm{l}^{-1} \text { at } 50 \text { DAS }\end{array}$ & $\begin{array}{l}\text { Improper application of } \\
\text { synthetic pesticides }\end{array}$ & Full gap \\
\hline
\end{tabular}


Impact of Cluster Front Line Demonstrations on Productivity and Economics of Lentil (Lens culinaris L.), Chickpea....

Maximum and minimum extension yield gaps were observed in field pea IPFD-10-12 (451 kg ha-1) during 2018/ 19 and in lentil var. IPL-406 (145 kg ha-1) during 2018/19 (Table 3). The extension yield gap in lentil varied from 162 $\mathrm{kg} \mathrm{ha}^{-1}(2017 / 18)$ to $321 \mathrm{~kg} \mathrm{ha}^{-1}(2020 / 21)$ and in case of chickpea, it was from $407 \mathrm{~kg} \mathrm{ha}^{-1}(2017 / 18)$ to $447 \mathrm{~kg} \mathrm{ha}^{-1}$ (2018/19).

Yield gap might be due to adoption of improved technology especially high yielding disease resistant varieties sown with balanced nutrient, seed treatment, weed management and plant protection measures in demonstrations which resulted in higher grain yield and higher economic returns than the traditional farmers' practices. The area of cultivation of lentil in Malda district is increasing day by day. Moreover in this region farmers are not habituated with the cultivation of field pea and chick pea but cultivation of chick pea in Malda district is little bit higher than field pea. So, the best result obtained with lentil followed by chickpea and field pea. Hence, for sustainable crop productions, there is an urgent need to aware and educate the resource poor farmers for the adoption of location specific technology to reduce the extension yield gap (Choudhary et al. 2010; Bhowmik et al. 2019).

\section{Technological yield gap}

The technological yield gaps were highest in field pea var. IPFD 10-12 (1113 $\left.\mathrm{kg} \mathrm{ha}^{-1}\right)$ during 2018/19 followed by chickpea var. JAKI-9218 (845 kg ha-1) during 2017/18 while lowest yield gap was observed in lentil var. KL-320 (481 kg ha $^{-1}$ ) during 2020/21. Irregular distribution of rainfall, differences in soil fertility, cultivation on marginal lands may be the possible reasons for the technological gaps observed in CFLDs even after strong management by the scientists in the demonstration plot. To minimize the yield gaps,

Table 3: Cluster frontline demonstrations on improved technology of field pea.

\begin{tabular}{|c|c|c|c|}
\hline $\begin{array}{l}\text { Technology } \\
\text { component }\end{array}$ & Demonstration package & $\begin{array}{l}\text { Farmers' } \\
\text { practices }\end{array}$ & GAP \\
\hline Variety & IPFD-10-12 & HUDP-154 & Full gap \\
\hline Seed rate & $100 \mathrm{~kg} \mathrm{ha}^{-1}$ & $110 \mathrm{~kg} \mathrm{ha}^{-1}$ & Higher seed rate \\
\hline Spacing & $22.5 \mathrm{~cm} \times 10 \mathrm{~cm}$ & Broadcasting & Full gap \\
\hline Sowing time & $1^{\text {st }}$ week of November & $3^{\text {rd }}$ week of November & Late sowing \\
\hline Seed treatment & $\begin{array}{l}\text { Rhizobium culture and PSB } 1 \times 10^{7} \mathrm{CFU} \mathrm{g} \mathrm{g}^{-1} @ 10 \mathrm{gm} \mathrm{kg}^{-1} \\
\text { of seed one day before sowing of seeds }\end{array}$ & No seed treatment & Full gap \\
\hline $\begin{array}{l}\text { Fertilizer } \\
\text { (NPK as basal) }\end{array}$ & $\mathrm{N}: \mathrm{P}_{2} \mathrm{O}_{5}: \mathrm{K}_{2} \mathrm{O}\left(20: 40: 40 \mathrm{~kg} \mathrm{ha}^{-1}\right), \mathrm{ZnSO}_{4} @ 20 \mathrm{~kg} \mathrm{ha}^{-1}$ & 10:10:10 & Lower doses \\
\hline D.A.P. & $2 \%$ D.A.P. @ $9 \mathrm{~kg} \mathrm{ha}^{-1}$ at 30 DAS as foliar spray & No such treatment & Full gap \\
\hline Micronutrients & $\begin{array}{l}\text { Micronutrient grade } \vee @ 900 \mathrm{ml} \mathrm{ha}^{-1} \text { at } 35 \text { DAS during } \\
\text { vegetative stage and at } 60 \text { DAS during pre-flowering } \\
\text { stage with sticker @ } 225 \mathrm{ml} \mathrm{ha}^{-1}\end{array}$ & No such treatment & Full gap \\
\hline Irrigation & Pre-flowering and pod initiation stage & One at 35 DAS & Partial gap \\
\hline Soil treatment & 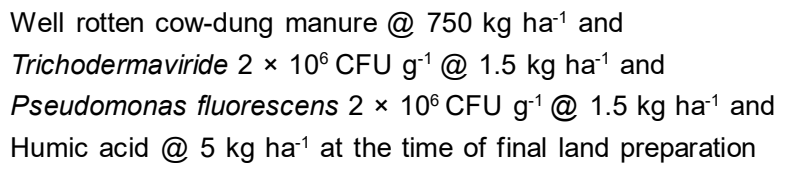 & No such treatment & Full gap \\
\hline Weed management & Pendimethalin $30 \%$ as PE @ $0.75 \mathrm{~kg}$ a.i. ha ${ }^{-1}$ & One hand weeding & Uneconomical \\
\hline Plant protection & Spinosad $0.2 \mathrm{ml} \mathrm{l}^{-1}$ at 50 DAS & No such practice & Full gap \\
\hline
\end{tabular}

Table 4: Location and soil properties of the villages under CFLD on Pulses.

\begin{tabular}{|c|c|c|c|c|c|c|c|c|c|c|}
\hline \multirow{3}{*}{ Block name } & \multirow{3}{*}{$\begin{array}{l}\text { No. of } \\
\text { village }\end{array}$} & \multirow{3}{*}{$\begin{array}{l}\text { No. of } \\
\text { farmer }\end{array}$} & \multicolumn{8}{|c|}{ Soil properties } \\
\hline & & & \multicolumn{3}{|c|}{ Physical character } & \multicolumn{5}{|c|}{ Available nutrients $(\mathrm{kg} / \mathrm{ha})$} \\
\hline & & & $\mathrm{pH}$ & EC (\%) & $\mathrm{OC}(\%)$ & $\mathrm{N}$ & $\mathrm{P}$ & $\mathrm{K}$ & $\mathrm{B}$ & $\mathrm{Zn}$ \\
\hline Ratua-I & 3 & 27 & 7.39 & 0.25 & 0.69 & 654.1 & 69.8 & 342.1 & 75 & 80 \\
\hline Ratua-I & 3 & 30 & 7.30 & 0.13 & 0.12 & 675.5 & 43.8 & 287.9 & 50 & 79 \\
\hline Ratua-I & 3 & 26 & 6.55 & 0.12 & 0.14 & 365.9 & 85.4 & 196.5 & 67 & 34 \\
\hline Ratua-I & 2 & 20 & 6.98 & 0.42 & 0.43 & 480.3 & 98.1 & 213.6 & 89 & 65 \\
\hline Ratua-II & 2 & 37 & 6.75 & 0.15 & 0.19 & 360.4 & 80.3 & 190.9 & 37 & 54 \\
\hline Chanchal-I & 1 & 7 & 6.54 & 0.15 & 0.75 & 350.0 & 41.7 & 150.9 & 34 & 49 \\
\hline Chanchal-II & 4 & 28 & 7.60 & 0.11 & 0.84 & 359.5 & 43.7 & 155.9 & 40 & 58 \\
\hline Gazole & 2 & 25 & 6.94 & 0.25 & 0.22 & 353.4 & 84.5 & 192.8 & 39 & 59 \\
\hline Manikchak & 1 & 5 & 7.54 & 0.23 & 0.52 & 476.9 & 77.5 & 269.7 & 47 & 62 \\
\hline
\end{tabular}


Impact of Cluster Front Line Demonstrations on Productivity and Economics of Lentil (Lens culinaris L.), Chickpea....

Table 5: Crop-wise results of demonstration with improved technology under CFLD on pulse during 2017/18-2020/21.

\begin{tabular}{lccccccccccc}
\hline Year & Crop & Variety & $\begin{array}{c}\text { No. of } \\
\text { Demonstration }\end{array}$ & $\begin{array}{c}\text { Area } \\
(\mathrm{ha})\end{array}$ & $\begin{array}{c}\text { PY } \\
(\mathrm{kg} / \mathrm{ha})\end{array}$ & $\begin{array}{c}\text { ADY } \\
(\mathrm{kg} / \mathrm{ha})\end{array}$ & $\begin{array}{c}\text { YLC } \\
(\mathrm{kg} / \mathrm{ha})\end{array}$ & $\begin{array}{c}\text { POLC } \\
(\%)\end{array}$ & $\begin{array}{c}\text { TYG } \\
(\mathrm{kg} / \mathrm{ha})\end{array}$ & $\begin{array}{c}\text { EYG } \\
(\mathrm{kg} / \mathrm{ha})\end{array}$ & $\begin{array}{c}\text { TI } \\
(\%)\end{array}$ \\
\hline $2017-18$ & Lentil & IPL-406 & 25 & 10.0 & 1400.0 & 843.0 & 681.0 & 23.8 & 557.0 & 162.0 & 39.8 \\
$2018-19$ & Lentil & IPL-406 & 50 & 20.0 & 1400.0 & 897.0 & 752.0 & 19.3 & 503.0 & 145.0 & 35.9 \\
$2020-21$ & Lentil & KL-320 & 25 & 10.0 & 1600.0 & 1119.0 & 798.0 & 40.2 & 481.0 & 321.0 & 30.1 \\
$2017-18$ & Chick pea & Jaki-9218 & 25 & 10.0 & 2000.0 & 1155.0 & 748.0 & 54.4 & 845.0 & 407.0 & 42.3 \\
$2018-19$ & Chick pea & Jaki-9218 & 25 & 10.0 & 2000.0 & 1234.0 & 812.0 & 52.0 & 766.0 & 422.0 & 38.3 \\
$2020-21$ & Chick pea & NBEG-49 & 25 & 10.0 & 2000.0 & 1298.0 & 855.0 & 51.8 & 702.0 & 443.0 & 35.1 \\
$2018-19$ & Field pea & IPFD-10-12 & 25 & 10.0 & 2500.0 & 1387.0 & 936.0 & 48.2 & 1113.0 & 451.0 & 44.5 \\
\hline
\end{tabular}

$\mathrm{PY}=$ Potential yield, $\mathrm{ADY}=$ Average demonstration yield, $\mathrm{YLC}=$ Yield of local check, POLC= Percentage over LC, TYG $=$ Technology yield gap, EYG= Extension yield gap, $\mathrm{Tl}=$ Technology index.

Table 6: Crop-wise economic analysis of demonstration with improved technology under CFLD on pulse during 2017/18-2020/21.

\begin{tabular}{|c|c|c|c|c|c|c|c|c|c|c|c|}
\hline \multirow{2}{*}{ Year } & \multirow{2}{*}{ Crop } & \multirow{2}{*}{ Variety } & \multirow{2}{*}{ Season } & \multicolumn{2}{|c|}{ ACC (Rs./ha) } & \multicolumn{2}{|c|}{ AGR (Rs./ha) } & \multicolumn{2}{|c|}{ ANR (Rs./ha) } & \multicolumn{2}{|c|}{$\mathrm{BC}$ ratio } \\
\hline & & & & DP & FP & DP & FP & DP & FP & DP & FP \\
\hline $2017-18$ & Lentil & IPL-406 & Rabi & 12475 & 11050 & 37935 & 30645 & 25460 & 19595 & 2.04 & 1.77 \\
\hline 2018-19 & Lentil & IPL-406 & Rabi & 12647 & 11756 & 40365 & 33840 & 27718 & 22084 & 2.19 & 1.88 \\
\hline $2020-21$ & Lentil & $\mathrm{KL}-320$ & Rabi & 13022 & 12538 & 50355 & 35910 & 37333 & 23372 & 2.87 & 1.86 \\
\hline $2017-18$ & Chick pea & Jaki-9218 & Rabi & 15978 & 14274 & 57750 & 37400 & 41772 & 23126 & 2.61 & 1.62 \\
\hline 2018-19 & Chick pea & Jaki-9218 & Rabi & 16473 & 14628 & 61700 & 40600 & 45227 & 25972 & 2.75 & 1.78 \\
\hline $2020-21$ & Chick pea & NBEG-49 & Rabi & 16632 & 15308 & 64900 & 42750 & 48268 & 27442 & 2.90 & 1.79 \\
\hline 2018-19 & Field pea & IPFD-10-12 & Rabi & 18748 & 15847 & 69350 & 46800 & 50602 & 30953 & 2.70 & 1.95 \\
\hline
\end{tabular}

$\overline{\mathrm{ACC}}=$ Average cost of cultivation, $\mathrm{AGR}=$ Average gross return, $\mathrm{ANR}=$ Average net return, $\mathrm{DP}=\mathrm{Demonstration}$ plot, $\mathrm{FP}=\mathrm{Farmer}$ 's plot, $\mathrm{BC}=$ Benefit cost, $\mathrm{SP}=$ Sale price, $\mathrm{GP}=$ Grain produce.

strengthening the site specific crop management practices are essential.

\section{Technology index}

Potentiality of new technology in the farmers' field under existing agro climatic situations depends on technology index (Kumari et al. 2007). The technology will be more viable by lowering the technology index (Meena and Singh, 2017). The insufficient transfer of proven technology to cultivators and lack of adequate extension services for transfer of technology resulted higher technology index. In this present study, lowest and highest technology index were recorded in lentil var. KL-320 (30.1\%) during 2020/21 and field pea var. IPFD-10-12 (44.5\%) during 2018/19 (Table 5). Technology index ranging from $30.1 \%$ to $39.8 \%$ in lentil and $35.1 \%$ to $42.3 \%$ in chickpea were observed in demonstrated plots. In this present study, higher technology index might be due to recent introduction of all the varieties of lentil, chickpea and field pea in Malda district of West Bengal. Higher technology index in lentil during 2017/18 (Table 5) might be due to blast disease which is very common in Malda district due to fluctuation of temperature and occurrence of fog during the end of January and in case of chickpea, it is due to infestation of pod borer. The study reflected that low technology index can be achieved by adoptability of location specific proven technology along with introduction of high yielding disease resistant varieties and its proper demonstration under CFLDs' followed by intensive training and awareness campaign among the farming community in this region.

\section{Economic analysis of cluster front line demonstration on pulse}

Economic returns considered as a function of gain yield and selling price varied during different years. The benefit-cost ratio (BCR) varied between 2.04 (lentil var. IPL-406) to 2.90 (chick pea var. NBEG-49) in demonstration plots during 2017/18 and 2020/21, respectively. In farmers' plots, BCR were varied between 1.62 (chick pea var. B-108) to 1.95 (field pea var. HUDP-154) during 2017/18 and 2018/19, respectively (Table 6 ). The higher economic returns under demonstrations might be attributed due to improved technology, scientific monitoring and timely operations of crop cultivation.

\section{CONCLUSION}

Lentil var. KL-320, chickpea var. NBEG-49 and field pea variety IPFD-10-12 showed promising performances in Malda, West Bengal region. Moreover, lentil var. KL-320 (90120 days), chickpea var. NBEG-49 (90-105 days) and field pea variety IPFD-10-12 (110-115 days) are short duration in nature and so these varieties are more suitable to fit in various cropping systems.

Present study clearly indicated that due to technology and extension gaps, there exists a wide yield gaps among 
potential, demonstration and farmers' plots under pulses. Moreover, sluggish growth in yields and stagnant acreage are major concerns in pulse production in this region. It is also noted that varietal replacement coupled with improved agro-techniques can boost up pulse productivity, profitability and ultimately give livelihood security in a sustainable manner by increasing cropping intensity by diversifying their cropping system through introduction of pulses in Malda district. Improved farm technology has great impact on yield enhancement of crops reported in earlier studies of FLDs' (Kumar et al. 2016; Kumar et al. 2015; Sharma et al. 2012).

At last main emphasis will be made to disseminate the economically viable crop production technology along with short duration HYV'S suitable for local situation from small to large scale farmers' field through intensive training and demonstration for ensuring food and nutritional security to the resource poor farmers.

\section{REFERENCES}

Ali, M. and Gupta, S. (2012). Carrying capacity of Indian agriculture: Pulse crops. Current Science. 102(6): 874-881.

Anonymous (2019). Agricultural Statistics at a Glance 2019, Government of India, Ministry of Agriculture and Farmers Welfare, Department of Agriculture Cooperation and Farmers Welfare, Directorate of Economics and Statistics. pp. 80-86.

Anonymous (2016). Bureau of Applied Economics and Statistics, Department of Statistics and Programme Implementation, Government of West Bengal. pp. 42.

Bhowmik, P., Shajahan, M. and Biswas, P. (2019). Performance of improved integrated pest management (IPM) technology component for enhancing the productivity of kharif black gram (Vigna mungo L.) under cluster front line demonstration at Malda, West Bengal, India. International Journal of Current Microbiology and Applied Sciences. 8(10): 987-996.

Choudhary, A. K., Singh, A. and Yadav. D. S. (2010). On-farm testing of wheat cultivars for site specific assessment under varied bio-physical regimes in mid-hill conditions of Mandi district of Himachal Pradesh. Journal of Community Mobilization and Sustainable Development. 5(1): 1-6.

Cramb, R.A. (2003). Processes affecting the successful adoption of new technologies by smallholders. (In) Working with farmers: The key to the adoption of forage technologies. Hacker B (Ed).Food and Agriculture Organization of United Nations (FAO). 'FAOSTAT', 2018.

http:// www.fao.org/india/fao-in-india/india-at-a-glance Indian Institute of Pulse Research (2015). Vision 2050, pp. 9.

Kadian, K.S., Sharma, R. and Sharma, A.K. (1997). Evaluation of frontline demonstration trials on oilseeds in Kangra valley of Himachal Pradesh. Annals of Agriculture Research. 18(1): 40-43.

Khedkar R., Shinde V. and Chaudhari P. (2017). Role of Cluster Frontline Demonstrations in Enhancement of Chickpea Production. Journal of Krishi Vigyan. 6(1): 172-174.

Kumar, S., Singh, S., Sharma, P. and Sharma, M. (2015). Genetic divergence stability (AMMI) study in desi chickpea (Cicer aeritinum L.) under North Western Himalayas of Jammu Kashmir, India. Legume Research. DOI:10.18805/Ir.v0i OF.8410.

Kumar, S., Singh, P., Khar, S. and Sharma, M. (2016). Variability association studies screening of genotypes against pea seed borne mosaic virus (psmv) in lentil (Lens culinaris Medik.) under NW Himalayas of Jammu Kashmir. Legume Research. 39(1): 26-30.

Laguerre, G., Depret, G., Bourion, V. and Duc, G. (2007). Rhizobium leguminosarum bv. viciae genotypes interact with pea plants in developmental responses of nodules, roots and shoots. New Phytology. 176: 680-690.

Kumari, V., Kumar, A., Kumar, A. and Bhateria, S.(2007). Demonstration - an effective tool for increasing productivity of rapeseedmustard in Kangra district of Himachal Pradesh. Himachal Journal of Agricultural Research. 33(2): 257-261.

Meena, M.L. and D. Singh. (2017). Technological and extension yield gaps in green gram in Palidistrict of Rajasthan, India. Legume Research. 40(1): 187-190.

Sharma P.K., Kumar, S., Ishar A.K., Parkash, S. and Jamwal, S.S. (2012). Economic Impact of Front Line Demonstrations (FLD's) in Poonch district of Jammu and Kashmir. Economic Affairs. 57(1): 99-106.

The Hindu (2005). The Hindu Survey of Indian Agriculture.

Vilas, J., Mallikarjuna, S.N. and Gracy, C.P. (2018). Supplydemand gap analysis and projection for major pulses in India. Economic Affairs. 63(1): 277-285. 